ISSN No. 0974-035X

An indexed refereed \& peer-reviewed journal of higher education

Towards Excellence

UGC-HUMAN RESOURCE DEVELOPMENT CENTRE

Gujarat University, Ahmedabad-380009, Gujarat, India

\title{
RE/VISITING INFORMATION AND COMMUNICATION TECHNOLOGY IN TRADITIONAL INDIAN CLASSROOM
}

\author{
Prof Hitesh D Raviya \\ Mr Parth Dave \\ Ms Garima Tiwari
}

\begin{abstract}
In the 21st century, traditional Indian Classrooms have transformed over two decades: from overhead projectors and floppy disk to virtual reality (VR) and Augmented Reality (AR). Technological advancements and awareness have created a new avenue and vistas for language teaching and learning. The use of technology has been widely accepted as a pedagogical tool. However, academic scrutiny would highlight that even though ICT has been accepted as a pedagogical tool, very little attention has been paid to the holistic integration of ICT in the Curriculum Design, Content Development and Evaluation Methodology at the institutional level. This paper aims to provide an overview of ICT tools and platforms essential for student-centric, learning-centric classrooms and enable and empower students and teachers to blend technology in teaching in an immediate classroom environment and outside the classroom. The paper is a culmination of the researcher's two decades of experience and expertise as a researcher and teacher of English Language Teaching in higher education at various Higher Education institutions in the state of Gujarat.
\end{abstract}

Keywords: ICT, Content Development, Self-Learning, Higher Education

\section{Introduction}

Technology has always been at the forefront of human education. From the days of carving figures on rock walls to today, when most students are equipped with several portable 
Towards Excellence: An Indexed, Refereed \& Peer Reviewed Journal of Higher Education / Prof. Hitesh Raviya, Mr. Parth Dave \& Ms. Garima Tiwari / Page 450-459

technological devices at any given time, technology continues to push educational capability to new levels. In looking at where educational methods and tools have come from where they are going in the future, Technology's importance in the classroom is evident more than ever.

\section{Pre-Computer Classroom Technology}

In colonial times, Horn-Books used to help students in learning verses. In 1870, the magic lantern, a primitive version of a slide projector that projected images printed on glass plates, came into existence. The chalkboard came into use in 1890, followed by the pencil in 1900 . In the 1920s, a radio triggered an entirely new wave of learning, and as a result, on-air classes began. The overhead projector came in 1930, followed by the ballpoint pen in 1940 and headphones in 1950. The Videotape arrived in 1951, which was adapted as a new and exciting method of instruction. The Skinner Teaching Machine used to produce a combined system of teaching and testing, providing reinforcement for correct answers for the students came into the educational world in 1954, followed by a photocopier for mass production of material in 1959 and a handheld calculator fly and quick mathematical calculations in 1972. The Scantron system of testing, introduced by Michael Sokolski in 1972, helped educators grade more quickly and efficiently. Thus, in the pre-computer years, immediate response-type systems like video, calculator, Scantron had become a necessary part of Education.

\section{Computer-Aided Classroom Technology}

The first computer was developed in the $1930 \mathrm{~s}$, but a real computer for day-to-day life was introduced in the 1980s. The first portable computer introduced in 1981 was named "Man of

the Year" in 1982 by Time magazine. Toshiba released a laptop in 1985, and Apple's Mac was made available in 1984. In 1990, The World Wide Web came into existence due to HyperText Markup Language (HTML). After that, the Internet was made open for commercial use in 1993, due to which the world exploded into a frenzy of newfound research and communication methods. Apple released the first Personal Digital Assistants (PDAs) in 1993, and with that, computers became a part of every day. By the year 2009, 97\% of classrooms had one or more computers, and $93 \%$ of classroom computers had internet access. More than $40 \%$ of Students had started using computers often in their educational methods. Nowadays, college students are rarely without computer technology like a computer or a laptop or a smartphone with an active internet connection called Information and Communication Technology. 
Towards Excellence: An Indexed, Refereed \& Peer Reviewed Journal of Higher Education / Prof.

Hitesh Raviya, Mr. Parth Dave \& Ms. Garima Tiwari / Page 450-459

\section{Information and Communication Technology (ICT) and Education}

ICT refers to technologies that provide access to information through telecommunications. ICT is similar to Information Technology but focuses primarily on communication technologies and includes the Internet, wireless networks, computer, cell phones, and other communication mediums.

The integration of Information and Communication Technology (ICT) in education has provided more variation in teaching and training. The Function of ICT is systematic teaching and learning. ICT can significantly impact teachers' future in terms of the teacher's role, the methods of instruction, and the methods of assessment. In future, the role of a teacher will be changed from the sole knowledge provider to a facilitator or moderator; the methods of instruction will be changed from conventional discussions in the classroom to the use of online forums with the students; the medium of assessment will be changed from printed ones to e-assessment.

\section{Transformation of Education due to Technology}

It is needless to say that almost every aspect of life has been influenced by ICT in the last two decades. The impact of ICT on education since the advent of the World Wide Web has grown tremendously. ICT has created a new method of teaching/learning and research at all levels of Higher Education in India and all over the world. A few decades ago, technological devices like radio, television, film strips, overhead projector and video cassettes were used to make teaching effective and enhance learning. Nevertheless, nowadays, teaching and learning have been enhanced by ICT based technologies in interactive radio, teleconferencing, and web and satellite-based services.

At present, there is a flood of advanced technology worldwide, but our education system is not benefiting due to the lack of information and knowledge of teachers, students, and the administration. Students have their restrictions, teachers have their own, and the administration admits that the education system is really in poor shape today. The goal of this paper is to outline how information technology can help to create an education system that is based on the principles of helping teachers, students and administration to be effective in what they do, improving the quality and relevance of the teaching-learning process as the 
Towards Excellence: An Indexed, Refereed \& Peer Reviewed Journal of Higher Education / Prof. Hitesh Raviya, Mr. Parth Dave \& Ms. Garima Tiwari / Page 450-459

number of students under the online learning program doubled within ten years. There are many ways through which technology has impacted education in the current world.

Changes in the Higher Education Sector (India)

\section{Increasing Accessibility}

Technology has made education much more accessible than it used to be decades ago. Anyone can provide excess education through online courses from the comfort of their office or home, thanks to the Internet. All universities, colleges, and other higher learning institutions have diversified and can offer some of their course outlines. Online courses have made it easy for anyone to access their desired education through their computers and mobile devices. In this way, geographical barriers that hindered learning in the past have now been broken by Technology.

\section{Modernized Resources}

Spiral notebooks and three-ring binders have been replaced by laptops and tablets in today's technological era. Applications, class websites and other internet tools have enabled students to manage their course work online instead of using traditional textbooks, pen and paper. Ebooks are becoming a way of life in many learning institutions. For instance, literature students who are analyzing the fictional novel 1984 by George Orwell may surf online for the 1984 study guide without going to a physical library. Online libraries are also one way through which higher learning institutions are helping their students maximize learning resources. Learning resources have the advantage of being virtually instantaneous and comprehensive. Online resources also ensure an up-to-date information pool.

\section{Change of Role}

With the advent of technology in education, students and teachers' role is improving daily. The teacher was, in the past, the only source of information in the traditional classroom. The students only played the role of passive information receivers. The teacher's role is gradually changing from a sole information giver to "a guide on the side". Students are increasingly becoming more responsible for their learning by gathering information using Technology. Instructions of higher learning across the country are beginning to adopt this new learning model and redesigning their curriculum to incorporate Technology. 
Towards Excellence: An Indexed, Refereed \& Peer Reviewed Journal of Higher Education / Prof. Hitesh Raviya, Mr. Parth Dave \& Ms. Garima Tiwari / Page 450-459

\section{Expanded Opportunities}

Technology has expanded the opportunities for collaboration and communication. Learning collaboration was previously limited to other learners in the same building. Classrooms in traditional learning had been relatively isolated.

\section{Special Needs}

Special needs have for years been a critical issue in learning. In the past, the traditional classroom has been unable to take care of students who have special needs. The rigid and highly standardized procedures that teachers and students must go through neglect learners with special needs. The accessible and interactive nature of online learning creates an enabling environment for students with special needs to have an equal learning opportunity. Teachers can also use the various applications availed by Technology to assist learners with special needs.

\section{Digital Initiatives by the Ministry of Education}

Department of Higher Education, The Ministry of Education has been administering a National Mission on Education programme through Information and Communication Technology (NMEICT) to leverage the potential of ICT to make the best quality content accessible to all learners in the country free of cost. A few crucial initiatives under this programme are as under:

\section{SWAYAM}

The 'Study Webs of Active Learning for Young Aspiring Minds' (SWAYAM) is an integrated platform that offers online courses to the students of class $9^{\text {th }}$ to Post Graduate Level. The online courses are being used by the students and the teachers and non-student learners in the form of lifelong learning.

\section{SWAYAM Prabha}

SWAYAM Prabha is an initiative to provide 32 High-Quality Educational Channels through DTH (Direct to Home) across the country's length and breadth on a $24 X 7$ basis. It has curriculum-based course content covering diverse disciplines that aims at making quality learning resources accessible to remote areas where internet availability is still a challenge. 
Towards Excellence: An Indexed, Refereed \& Peer Reviewed Journal of Higher Education / Prof. Hitesh Raviya, Mr. Parth Dave \& Ms. Garima Tiwari / Page 450-459

\section{National Digital Library (NDL)}

The National Digital Library of India (NDL) is a project to develop a virtual repository framework of learning resources with a single-window search facility. There are more than three crore digital resources available through the NDL. The contents cover almost all major education domains and all significant levels of learners, including life-long learners.

\section{Spoken Tutorial}

They are a 10-minute long audio-video tutorial on open-source software to improve the employment potential of students. It is created for self-learning, audio dubbed into all 22 languages, and online versions. The Spoken Tutorial courses are effectively designed to train a novice user without a teacher's support

\section{Free and Open Source Software for Education (FOSSEE)}

FOSSEE is a project promoting the use of open-source software in educational institutions. It does through instructional material, such as spoken tutorials, documentation, textbook companions, awareness programmes, such as conferences, training workshops, and Internships. Textbook Companion (TBC) is a collection of code for solved examples of standard textbooks.

\section{Virtual Lab}

The Virtual Labs Project is to develop a fully interactive simulation environment to perform experiments, collect data, and answer questions to assess the understanding of the knowledge acquired. To achieve such an ambitious project's objectives, it is essential to develop virtual laboratories with state-of-the-art computer simulation technology to create real-world environments and problem handling capabilities.

\section{E-Yantra}

e-Yantra is a project for enabling effective education across engineering colleges in India on embedded systems and Robotics. The training for teachers and students is imparted through workshops where participants are taught the basics of embedded systems and programming. More than 275 colleges across India have benefited from this initiative.

\section{ICT as a pedagogical tool in English Language Teaching and Training}


Towards Excellence: An Indexed, Refereed \& Peer Reviewed Journal of Higher Education / Prof. Hitesh Raviya, Mr. Parth Dave \& Ms. Garima Tiwari / Page 450-459

The government, NGOs and educational institutions are working at various levels and taking measures to ensure better English Language Teaching (ELT) and developing English language skills. To teach the English language and develop English language skills, various approaches and methods are in use in our country. However, most of them are traditional, less attractive, ineffective, as well as less motivating. So, it is necessary to use modern approaches and tools of ICT (Information and Communication Technology) to understand better and acquire basic skills, i.e. LSRW (listening, speaking, reading and writing) of the English language among the students' school level.

ICT has many things to offer to both teachers and students to enhance their vocabulary and improve English language skills. Nowadays, ICT tools and approaches are being used widely due to their convenience, omnipresence, effectiveness, and economical. Some of these approaches, facilities and tools are CAI (Computer Assisted Instruction), CALA (Computer Assisted Language Assessment), CALI (Computer Assisted Language Instruction), CALL (Computer Assisted Language Learning), MALL (Mobile Assisted Language Learning), TELL (Technology Enhanced Language Learning), blogs, wiki, email facility, digital libraries, multimedia, mobile learning, free and open-source software and social media, MOOCs, virtual classrooms, documentaries, digital storytelling, mobile applications, i-Pads, digital notebooks, tablets, smartphones, recorded audio-video materials, online spoken tutorials, digital pronunciation dictionaries, etc. Modern studies and research show positive results of integrating ICT in English Language Teaching and the development of English language skills. These facilities have paved the way for individualized learning and provided freedom of learning to the learners according to their needs and convenience anytime, anywhere. So, we should take proper step to integrate ICT in English Language Teaching to make the learners well versed in English language skills.

The holistic integration of ICT in the Curriculum Design, Content Development and Evaluation Methodology at the institutional level has been neglected in Higher Education. Incorporation of ICT in the curriculum design is necessary to implement ICT in the classrooms. Various studies show that even after the government and education system is various valuable inputs and guidelines, the curriculum lacks a direct and active use of ICT.

Limitations of ICT Tools 
Towards Excellence: An Indexed, Refereed \& Peer Reviewed Journal of Higher Education / Prof.

Hitesh Raviya, Mr. Parth Dave \& Ms. Garima Tiwari / Page 450-459

Though ICT tools are beneficial in teaching and learning, still these tools have some limitations, as discussed below: -

1. The use of ICT tools needs techno-savvy and trained teachers.

2. Learners often fail to learn the targeted objectives.

3. There is a freedom of time and space that often makes learners careless about their targets and indulges them in meaningless work.

4. Repeated use of the same programmes creates boredom in the learners, leading to the problem of indiscipline in the classroom.

5. Most of the time, learners remain passive and inactive in the teaching-learning process because they get fewer opportunities to participate actively in the teachinglearning process.

\section{Conclusion}

A career in education requires hard work and dedication. For those who are serious about success in the education field, staying well-informed of current and changing technologies is imperative. As the world of Technology evolves, the learning environment, both on-campus and online, will equally progress, and the need for teachers who are educated in technology and design will continue to grow. ICT tools have changed the paradigm of the English language teaching-learning process. So a teacher needs to be familiar with modern ICT tools and use them properly to achieve the aims of English Language Teaching. 
Towards Excellence: An Indexed, Refereed \& Peer Reviewed Journal of Higher Education / Prof. Hitesh Raviya, Mr. Parth Dave \& Ms. Garima Tiwari / Page 450-459

\section{Works Cited}

Al-Kamel, Mohammed. "The Use of ICT Tools in English Language Teaching and Learning: A Literature Review.” Research Gate, https://www.researchgate.net/publication/330986788_The_Use_of_ICT_Tools_in_Engl ish_Language_Teaching_and_Learning_A_Literature_Review.

Bonner, Euan and Hayo Reinders. "Augmented and Virtual Reality in the Language Classroom: Practical Ideas.” Research Gate, https://www.researchgate.net/publication/328781217_Augmented_and_Virtual_Reality _in_the_Language_Classroom_Practical_Ideas.

Brett, P., and G. Motteram. Special interest in computers: learning and teaching with information and communications technologies, ICT. IATEFL, 2000.

Hisham. Understanding The Role Of ICT In Higher Education. Fedena Blog. https://fedena.com/blog/2020/06/understanding-the-role-of-ict-in-highereducation.html.

IGI Global. Teacher training and professional development: concepts, methodologies, tools, and applications, 2018.

Latwal, Gopal Singh, et al., editors. Role of ICT in Higher Education: Trends, Problems, and Prospects. Apple Academic Press, 2020.

NIC, L. P. Ministry of Human Resource Development, Department of Higher Education. Department of Higher Education | Government of India, Ministry of Education. https://www.mhrd.gov.in/ict-initiatives.

Oliver, Ron. "The role of ICT in higher education for the 21 st century: ICT as a change agent for education." Research Gate, https://www.researchgate.net/publication/228920282_The_role_of_ICT_in_higher_edu cation_for_the_21st_century_ICT_as_a_change_agent_for_education.

Prestridge, S. Engaging with the transforming possibilities of ICT. Australian Educational Computing, 2007.

Pelgrum, W. J. Obstacles to the integration of ICT in education: results from a worldwide educational assessment. Computers \& Education, 2001.

Sicilia, C. The Challenges and Benefits to Teachers' Practices in Constructivist Learning Environments Supported by Technology. Unpublished master's thesis, McGill University, Montreal, 2005.

\section{Prof Hitesh D Raviya}

\section{Head, Department of English, Vice Dean, Faculty of Arts,}


Towards Excellence: An Indexed, Refereed \& Peer Reviewed Journal of Higher Education / Prof. Hitesh Raviya, Mr. Parth Dave \& Ms. Garima Tiwari / Page 450-459

The Maharaja Sayajirao University of Baroda, Vadodara \& Mr Parth Dave Assistant Professor, Department of English, The Maharaja Sayajirao University of Baroda, Vadodara \& Ms Garima Tiwari Assistant Professor, Department of English, The Maharaja Sayajirao University of Baroda, Vadodara 